\title{
CENGKOK SINDHEN BERGAYA POP SEBAGAI PENDUKUNG INDUSTRI HIBURAN
}

\author{
Siswati \\ Dosen Jurusan Karawitan Fakultas Seni Pertunjukan \\ Institut Seni Indonesia (ISI) Surakarta \\ Email: siswaticyoi@gmail.com
}

\begin{abstract}
Abstrak
Penelitian ini mengkaji mengenai munculnya sindhen di acara-acara televisi dan dunia maya dengan tampilan yang berbeda. Perbedaan tampilan ini mengacu pada sajian lagu-lagu pop yang berbeda dari sindhen pada umumnya. Hipotesis terkait dengan perubahan tampilan berupa lagu lintas genre tersebut, bahwasanya para sindhen mempunyai tujuan utama eksistensi yang berdampak pada penghasilan finansial. Penggunaan kata "sindhen" sebagai label industri akan merubah makna sindhen yang sesungguhnya. Penelitian ini mengambil sampel sindhen yang terjun ke musik lintas genre. Metode penelitian yang digunakan adalah kualitatif dengan pendekatan studi kasus. Hasil penelitian adalah ekonomi merupakan aspek kuat yang melatarbelakangi kemauan untuk menjadi sindhen lintas genre. Dikotomi status sosial dalam masyarakat bahwa memegang erat posisi seni tinggi dan seni rendah. Hal tersebut menjadikan seseorang merasa mempunyai beban kultural sehingga membatasi kebebasan ekspresi dalam dirinya. Serta menjaga kualitas dengan latihan.
\end{abstract}

Kata kunci: cengkok sindhen, lintas genre, gaya pop, industri hiburan.

\begin{abstract}
This study examines the emergence of sindhen in television shows and cyberspace with different views. This display difference refers to the dish of pop songs that are different from sindhen in general. The hypothesis associated with the change of appearance in the form of songs across the genre, that sindhen have the main purpose of existence that impact on financial income. The use of the word "sindhen" as an industry label will change the true meaning of sindhen. This study takes samples of sindhen that plunge into music across genres. The research method used is qualitative with case study approach. The result of this research is economics is strong aspect which is background of willingness to become sindhen cross genre. The dichotomy of social status in society that holds tightly the position of high art and low art. It makes a person feel has a cultural burden that limits freedom of expression in him. As well as maintaining quality with practice.
\end{abstract}

Keywords: cengkok sindhen, cross genre, pop style, entertainment industry .

\section{Pengantar}

Sindhen berawal dari kata sindi (bahasa Kawi) yang berarti sindiran, sindyan merupakan nyanyian yang menggunakan sindiran (Zoetmulder, 2011;1094). Pandangan masyarakat secara umum, sindhen adalah perempuan yang duduk bersimpuh menyajikan tembang jawa lengkap dengan segala atributnya (sanggul, kebaya, kain batik)
(Kompas, 8 Maret 1999). Dengan demikian, dapat dipahami bahwa sindhen ialah seorang wanita dengan atributnya menyajikan tembang jawa dengan syair sindiran (tidak langsung) dalam tangga nada pentatonis (pelog dan slendro).

Dewasa ini kekhawatiran tentang sindhen muncul dari berbagai pihak salah satu di antaranya POVW (Pusat Olah Vokal Waranggana) sebagai lembaga yang berkaitan 
karena minat masyarakat menjadi sindhen mulai surut. (Kompas, 25 September 2004). Pada pendidikan formal nampak bahwa pesindhen dalam kalangan kaum muda tidak begitu banyak diminati, apalagi setelah mengalami proses pembelajaran, tidak dapat dihindari bahwa seleksi alam juga turut menentukan kesetiaan dari para siswi tersebut. Tidak heran apabila jumlah mahasiswi yang mampu menyelesaikan studinya hanya sekitar 10-20\% saja (Kompas, 21 Maret 2010).

Hal-hal yang mengindikasi surutnya peminat sindhen di antaranya adalah masalah proses. Proses pembelajaran sindhen tergolong sulit, ketekunan dan niat yang kuat sangat diperlukan supaya proses belajar yang lama tidak membuat jenuh dan malas. Selain itu durasi pertunjukan yang memerlukan sedikitnya 4-8 jam dalam sekali pertunjukan, duduk bersimpuh mengenakan busana yang singset (Kompas, 25 September 2004).

Faktor selanjutnya yakni pendapatan atau hasil fimamsial, tidak adanya kepastian tanggapan atau order pentas sehingga perolehan finansial tidak bisa dipastikan. Tergantung pada momen kesenian di antaranya acara bersih desa, pernikahan, ulang tahun dan peringatan. (Kompas, 25 September 2004). Ditambah lagi dengan stigma miring (prostitusi) yang selalu mengelilingi kehidupan sindhen (Kompas,16 November 1996). Fenomena mengenai turunnya minat sindhen tersebut, memunculkan sebuah kekhawatiran sebagaimana yang dipaparkan salah satu dalang terkenal yakni Ki Enthus Susmono yang mencemaskan akan terjadinya pengklaiman sindhen oleh negara lain

Bukti tentang sindhen yang digemari oleh warga negara asing karena sudah banyak WNA menjadi sindhen di antaranya Hiromi Kano (49 th) asal Jepang dan Megan O'Donoghue asal Amerika yang saat ini berprofesi sebagai sindhen di Indonesia (Suaramerdeka.com, 3 September 2014). Semakin tingginya intensitas pentas akan berpengaruh terdahap kualitas sindhen yang berdampak pada penghargaan terutama pengakuan dari masyarakat akan profesinya sebagai sindhen.
Secara umum dalam konteks pertunjukan, tampak bahwa sindhen-sindhen muda yang belajar secara formal tidak hanya memiliki pengetahuan mengenai cara membaca dan menuliskan teori sindhenan tetapi juga memiliki kemampuan untuk memainkan instrumen gamelan. Hal tersebut terjadi karena pada pendidikan formal mereka dituntut untuk mampu menguasai semua instrumen gamelan mulai dari instrumen depan (rebab, kendang, gender, gambang) sampai instrumen belakang (saron, bonang, kenong dan gong) (Kompas, 16 November 1996).

Oleh karena itu, seorang sindhen yang mengenyam pendidikan formal lebih cepat menyerap materi baru karena mereka memiliki pengetahuan membaca teori sindhenan. Selain itu, mereka pun dapat menerangkan dan menjelaskan secara lebih rinci kepada masyarakat umum mengenai seluk-beluk teori sindhen dan mempraktikkannya dengan lebih terstruktur.

Kini profesi sindhen kembali marak setelah beberapa stasiun televisi swasta menampilkan pesindhen (Info Musika BBC Indonesia, 3 Maret 2013). Beberapa pesindhen "gaul" lintas genre sebagai penghibur mewarnai tayangan televisi, di antaranya Soimah yang mengawali karirnya sebagai sindhen wayang, penyanyi campursari, kethoprak dan bergabung dengan berapa komunitas kesenian yang ada di Yogyakarta. Karir Soimah kemudian berlanjut dengan menjadi ikon acara hiburan televisi "Segerrr Benerrr" produksi ANTV (Kompas, 21 Maret 2010).

Silir Pujiwati kelahiran Temanggung ikut menerobos dalam dunia industri musik sebagai sindhen, penyanyi keroncong, pop melalui komunitas Kua Etnika dan Orkes Sinten Remen pimpinan Djaduk Feriyanto. Selain itu, ada dua bersaudara yang samasama terjun di ranah musik industri yaitu Endah Laras dan Sruti Respati. Keduanya sama-sama berangkat dari pengalaman dan kemampuan menyinden.

Sosok lain yang cukup dikenal sebagai sindhen lintas genre adalah Peni Candrarini. Ia adalah seorang pengajar di ISI Surakarta 
yang telah mengukir banyak prestasi dalam musik selain karawitan. Peni Candrarini mendapat penghormatan sebagai maskot SIPA (Solo International Performing Art) ke-8 di tahun 2016 dengan tema Mahaswara. Sebagai maskot SIPA, berlatar belakang sindhen namun mampu berkolaborasi dengan beberapa seniman dan komposer dari dalam maupun luar negeri (Solo.Tribunnews.com 08 September 2016).

Berpijak dari kelima contoh pesindhen di atas dan pengalaman di lapangan, sebagian sindhen memiliki kemampuan bernyanyi tidak hanya dalam repertoar gamelan saja tetapi juga dari berbagai jenis musik di luar bidangnya. Hal itulah yang mendorong beberapa di antaranya menjadi sindhen lintas genre dan menjadi dikenal banyak orang, bahkan terjun dalam dunia industri. Sejauh ini masyarakat menerima hal tersebut, bahkan memberi pengakuan sebagai sindhen lintas genre karena memberi warna baru dengan menggabungkan musik tradisional dan musik barat. (Solo.Tribunnews.com 08 September 2016). Fenomena tersebut sangat menarik karena hadirnya sindhen lintas genre dalam dunia industri mempengaruhi pandangan masyarakat umum dalam menilai profesi sindhen.

Melalui informasi tersebut dapat diasumsikan bahwa pada praksisnya sindhen memiliki posisi di depan instrumen gamelan. Selain berperan sebagai penghias/pemanis pada ansambel gamelan, sindhen memiliki kesempatan untuk mengembangkan karirnya sendiri. Meskipun saat ini banyak sindhen yang berusaha mempelajari genre lain tetapi kenyataanya aura sindhen masih melekat pada hasil produksi suara yang dilantunkan. Disisi lain ternyata ada sebagian sindhen yang bisa menyinden dan menyanyi dalam genre lain dengan baik.

Mengingat proses belajar sindhen yang sulit, tentunya para sindhen memiliki cara tersendiri dalam mempelajari teknik-teknik nyanyian lintas genre. Pesindhen yang menyajikan lagu lintas genre mampu menarik banyak perhatian dari khalayak umum. Dampaknya sangat terasa dari popularitas dan sisi ekonomi, sindhen yang menyanyi lintas genre mendapatkan honorarium lebih baik dibanding dengan sindhen yang tidak bisa bernyanyi pop (Sindhen klasik). Durasi dan frekuensi pentas Sindhen tradisi lebih lama tetapi pendapatan honorarium mereka tidak sebanding dengan durasi pekerjaannya.

Secara positif munculnya sindhen di televisi dengan pengemasan yang berbeda memberikan kontribusi yang baik sebagai pengenalan dan pemahaman akan arti sindhen. Tetapi di satu sisi ada kekhawatiran bahwa fenomena tersebut mengubah makna sindhen yang sebenarnya dan label sindhen hanya dimanfaatkan bagian dari industri musik.

Perlu adanya identifikasi yang lebih detail mengenai cara, usaha, atau potensi dari pesindhen yang memiliki kemampuan bernyanyi lintas genre agar dapat diperoleh pengetahuan baru dalam meningkatkan ketrampilan olah vokal seorang pesindhen sehingga secara tidak langsung akan memperluas kemampuan partisipatif dalam dunia industri sekaligus dalam upaya mengembangkan seni tradisi.

\section{Pembahasan}

Sindhen di wilayah Yogyakarta dan Surakarta masih banyak dijumpai dalam pertunjukan gamelan seperti wayang, kethoprak, uyon-uyon dan pengiring tari klasik. Dalam pementasannya, sindhen selalu diiringi dengan musik gamelan. Karena keduanya merupakan satu kesatuan yang tidak dapat dipisahkan.

Pertunjukan gamelan memiliki durasi pentas yang berbeda. Dalam sekali pertunjukan gamelan murni berkisar antara 18 jam bergantung pada kebutuhan pertunjukan (wayang, tari, kethoprak atau uyon-uyon). Sebagian acara yang menggunakan gamelan, lebih banyak menggunakan waktu malam karena gamelan digunakan oleh masyarakat sebagai hiburan saat cegah wungon atau bergadang ketika ada hajatan. Hajatan yang menggunakan pertunjukan gamelan dan melibatkan sindhen 
banyak dijumpai dalam acara pernikahan, bersih desa, syukuran, upacara adat, peresmian tempat bahkan kampanye dan festival.

Sindhen konvensional menurut masyarakat berada dalam ranah hiburan yang bersifat adiluhung dan hanya dinikmati oleh kalangan tertentu (penikmat karawitan dan bersifat kelangenan). Masyarakat karawitan yang paham tentang sindhen akan menyebut sebagai sindhen ketika seseorang tersebut mengetahui akar, dasar karawitan dan mampu nyindhen untuk kebutuhan mandiri atau iringan sehingga apa yang dilantunkan merupakan kesatuan intra dan ekstra musikal. Selain itu nada atau lagu sindhen berada dalam wilayah pentatonis (pelog dan slendro). Sedangkan penyebutan bagi orang yang hanya bisa melantunkan tembang jawa dengan sedikit cengkok sindhen disebut sebagai penembang jawa belum tepat untuk mendapat julukan sindhen.

Sindhen dengan segala atribut seperti sanggul, kebaya, kain batik, dan aksesoris menempatkan dirinya sebagai bagian dari ansambel gamelan. Sindhen berfungsi sebagai penghias dan memperindah repertoar gending dilakukan dengan posisi duduk bersimpuh dari awal pergelaran sampai selesai pertunjukan. Kebutuhan sindhen dalam pertunjukan gamelan berbeda-beda.Terkadang 1-3 orang (uyon-uyon dan iringan kethoprak/tari) namun bisa sampai 12 sindhen (pertunjukan wayang Ki Seno Nugroho).

Untuk pertunjukan wayang dengan banyak sindhen membutuhkan tempat tersendiri yakni berada terpisah dengan ansambel gamelan. Para sindhen biasanya berada di panggung sebelah kiri, menempati posisi duduk menghadap ke penonton. Sudah menjadi kebiasaan setiap pertunjukan wayang bahwa crew panggung memberikan tempat duduk untuk sindhen setara dengan posisi dalang dan lebih tinggi dibanding panggung ansambel gamelan. Hal tersebut disesuaikan dengan kebutuhan karena beberapa dalang ada yang menghendaki posisi duduk sindhen jadi satu dengan ansambel gamelan ( saat pagelaran wayang di Sasana Hinggil oleh dalang Ki Cermo Sutejo) meski jumlah sindhen lebih dari 5 orang.

Sindhen akan mempunyai posisi duduk setara dengan ansambel gamelan saat uyonuyon atau pengiring pertunjukan tari dan kethoprak. Hal ini karena porsi sindhen untuk kebutuhan iringan. Sebagai bentuk pertunjukan mandiri atau uyon-uyon, sindhen mempertimbangkan relasi musikalnya sehingga lebih mengutamakan hasil produksi suaranya.

Pada umumnya seorang pesidhen identik dengan kesopanan berbusana (berkebaya panjang dan sanggul) dan selalu berwibawa di atas pangung. Ia harus selalu menjaga etika dan nilai keklasikan budaya sindhen itu sendiri, sebagaimana yang telah diwariskan secara turun temurun dalam budaya sebelumnya.

Meski demikian dari keseringan bersindhen, tidak menutup kemungkinan seorang pesindhen perlu selalu mengembangkan bakat dan talenta yang ia miliki. Dalam artian bahwa, selain bersindhen dalam aturan klasik pementasan pada ritual sakral dan hiburan (yang terikat pada tata busana dan etitut), seorang pesindhen pun bisa bernyanyi dan mengekspresikan diri dalam lagu genre lain.

Namun dari sekian banyak pesindhen yang sering melibatkan diri dalam pementasan, mereka memiliki kemampuan yang berbeda-beda. Dalam banyak kesempatan, sering dijumpai ada pesindhen yang bisa bernyanyi dan mengekspresikan diri dalam lagu genre lain, seperti dangdut, keroncong, dan jazz, sedangkan sebagian pesindhen lain tidak bisa.

\section{Sindhen Lintas Genre}

Sindhen sekarang telah mengalami beberapa perubahan seiring berjalannya waktu. Hal tersebut dikarenakan oleh beberapa faktor yang mempengaruhi di antaranya adalah pilihan pesindhen itu sendiri, lingkungan, kesempatan dan keberuntungan. Dilihat dari sajian-sajian dan repertoar lagunya yang kebanyakan lebih memilih lagu bukan pada wilayah pentatonis namun lebih 
kepada genre-genre diwilayah nada diatonis yang disukai oleh banyak orang seperti dangdut, jazz, pop dan keroncong.

Sindhen lintas genre tampil dengan musik non gamelan. Musik lain yang sama sekali berbeda wilayah nadanya di antara alat musik diatonis dan alat musik tradisi daerah lain. Posisi menyanyi dan menyindhen dalam keadaan berdiri, selain mengimbangi musisi yang mengiringi, juga beradaptasi dengan keadaan panggung yang tidak menuntut untuk para sindhen duduk bersimpuh. Hal ini semakin menambah tampilan sindhen sebagai penyanyi lintas genre semakin berpotensi untuk berekspresi dan berinteraksi dengan para penonton.

Hakikat sindhen tetap sebagai penghias lagu, namun lagu yang dibawakan sindhen lebih kepada lirik lagu pop (bukan sindhenan). Sindhen masih bersifat hiburan namun cakupan audiennya lebih meluas ke semua kalangan (bukan hanya penikmat hiburan pada ansambel gamelan/karawitan). Sehingga profesi sindhen menjadi terkenal di khalayak umum.

Beberapa sindhen yang bisa bernyanyi lintas genre di antaranya adalah Endah Laras, Silir Pujiwati dan Peni Candrarini. Penyebutan selanjutnya akan ditulis secara inisial yaitu Endah Laras (EL), Silir Pujiwati (SP) dan Peni Candrarini (PC). Ketiga wanita tersebut merupakan ibu rumah tangga yang pernah menempuh bangku pendidikan di bidang karawitan. (EL) dan (PC) berangkat dari keluarga seni terutama gamelan dan wayang sehingga sudah mengenal karawitan sejak kecil. Sedangkan (SP) dari keluarga petani akan tetapi mempunyai hobi bernyanyi. Melihat hal tersebut aktivitas tarik suara sudah tertanam sejak dini.

(EL), (SP) dan (PC) serius menekuni bidangnya setelah menemukan dirinya berada pada posisi strategis dalam bernyanyi lintas genre. Momentum yang bagus menjadikan mereka semakin terkenal di masyarakat luas. Oleh sebab profesi yang dijalani sekarang, sebagian orang terutama masyarakat karawitan tidak lagi menyebutkan profesi mereka sebagai sindhen lagi. Namun bagi orang awam ketika mereka melantunkan sedikit ciri khas sindhen atau pentas bersama dengan ansambel gamelan bertentunya akan dipanggil sebagai seorang pesindhen.

\section{Cengkok Sindhen Lintas Genre}

Selain dari warna suara, untuk membedakan genre lagu dapat dilihat dari unsur musikal yaitu ornamentasi atau cengkok. Sehingga munculnya cengkok seseorang bisa memberikan identitas atau karakter seseorang dalam menyanyi. Hal ini tentunya untuk membedakan jenis musik apa yang dinyanyikan.

Sindhen yang mengusai ornamentasi lagu dan cengkok sindhenan memiliki banyak peluang didunia industri. Perubahan itu mengangkat popularitas sindhen. Sehingga dengan kemampuannya itu membuat sindhen memiliki posisi tersendiri di masyarakat pada umumnya. Hasil nyanyian yang dilantunkan merupakan peleburan dari ornamentasi lagulagu dan berbagai cengkok yang dilakukan sehingga membuatnya mempunyai keunikan dan menjadi ciri atau style sindhen tersebut .

Hal itu sebagai akibat dari interaksi sosial yang dilakukan ketika seseorang mau membuka diri dengan ikhlas dan tidak ada beban kultur. Seperti pernyataan (SP) berikut ini bahwa dengan mempunyai kemampuan tersebut menjadi sesuatu yang mahal dan tidak banyak dilakukan oleh banyak orang. Kemampuannya dalam mengolah cengkok digunakan sebagai peluang emas dalam mendapatkan posisi di hati masyarakat secara luas. Karena dengan mengetahui karakter masing- masing cengkok lagu membuatnya berada dalam posisi yang strategis dan dapat diterima di masyarakat pada umumnya.

\section{Motivasi Menjadi Sindhen Lintas Genre}

Adorno dalam Budiarto (2001) mengatakan bahwa budaya populer (budaya pop) merupakan kumpulan fenomena kehidupan yang banyak dipengaruhi oleh media massa. Budaya pop tidak terlepas dari budaya industri. Oleh karena itu hasil 
karyanya sudah tentu sebagai barang dagangan. Tujuan utamanya untuk mencari keuntungan.

Kehidupan masyarakat sebagian besar berada dalam ekonomi kelas menengah kebawah. Oleh sebab itu dengan menjadi seorang seniman terutama sindhen akan mendapatkan kesejahteraan finansial dengan lebih cepat. Dari narasumber primer tersebut, satu diantaranya berada pada posisi sebagai anak sulung. Kebanyakan orang Jawa, ketika seseorang dilahirkan menjadi anak pertama apalagi memiliki saudara yang banyak dan jarak kelahirannya dekat membuat si sulung mempunyai rasa tanggung jawab yang lebih terhadap keluarganya. Salah satu tanggung jawab yang tersemat dalam diri si sulung adalah tanggung jawab ekonomi. Apalagi jika seorang bapak memiliki darah seni yang kuat akan mempengaruhi jiwa kesenimanan sang anak yang berujung pada pengharapan finansial.

Selanjutnya (Caturwati, 2005: 572-573) mengatakan bahwa pendapatan ekonomi yang diperoleh dengan menjadi sindhen lebih besar dibanding pekerjaan masyarakat kelas menengah kebawah lainnya. Tujuan utama para wanita menjadi sindhen adalah faktor ekonomi. Ketika seseorang memiliki kebutuhan ekonomi yang lebih besar, maka apapun akan dikorbankan karena ekonomi tersebut berkaitan dengan keberlangsungan hidup seseorang. Terkait pernyataan Caturwati tentang pendapatan ekonomi, hal ini memacu seorang sindhen untuk memilih posisi yang memberikan kenyamanan secara finansial.

Meski tuntutan menjadi seorang sindhen beberapa waktu lalu berbeda dengan sekarang ini namun jumlahnya semakin banyak. Ini disebabkan karena penghargaan terhadap sindhen semakin baik. Sekarang ini masyarakat menginginkan lebih dari pada sebatas sindhen konvensional. Oleh karena itu seorang sindhen harus mampu mengikuti tuntutan jamannya supaya perolehan kebutuhan ekonomi tetap stabil dan tercukupi. Salah satu caranya adalah dengan menjadi sindhen lintas genre.
Dari analisis diatas didapatkan pemahaman baru bahwa peluang finansial dengan menjadi sindhen lintas genre yang menguasai berbagai cengkok musik apapun dan bisa beradaptasi sesuai dengan perubahan animo kesenian masyarakat menjadi sangat menguntungkan. Dikatakan menguntungkan karena dengan kemampuannya tersebut seorang sindhen lebih bisa fleksibel.

Jadwal pentas yang semakin banyak dan masyarakat pendengarnya juga luas membuat para sindhen lintas genre ini semakin eksis. Eksistensinya semakin naik karena beberapa faktor diantaranya bahwa generasi sindhen sebelumnya tidak banyak bahkan mungkin belum ada yang melakukannya. Selanjutnya dengan munculnya sindhen lintas genre ini dianggap masyarakat sebagai hal baru yang menjawab kebutuhan musik mereka. Sehingga semakin banyak kesempatan untuk pentas semakin banyakjuga peluang finansial yang diperolehnya.

\section{Cengkok Sindhen dan Gaya Pop}

Cengkok merupakan istilah yang digunakan untuk menyebutkan bagian lagu yang identik dengan lenggak lenggoknya atau hiasan suara berdasarkan jenis lagunya. Beberapa genre musik yang menggunakan istilah cengkok yaitu keroncong, karawitan dan dangdut. Masing-masing cengkok pada jenis musik tersebut memiliki kekhasan dan karakter sendiri. Sedangkan dalam jenis musik pop dan jazz lenggak lenggok tersebut disebut dengan ornamentasi.

Dalam sindhenan jawa, sebuah cengkok terdiri dari luk dan gregel, dimana bagian tersebut akan menambah indahnya sindhenan. Luk sindhenan biasanya terdiri dari minimal dua nada dan nada yang dibunyikan jelas alurnya. Namun jika luk tersebut ditempatkan pada tempo yang lebih lambat, untuk menyesuaikannya biasanya muncul gregel, dimana gregel berarti hiasan nada atau vibrasi antara awal dan akhir luk. Gregel atau vibrasi sindhen berbeda dengan vibrasi keroncong. Jangkauan nada dalam vibrasi sindhen lebih banyak serta lebih rapat. 
(Witkin, 2003: 100-102) menerangkan bahwa detail dalam musik populer yang dijelaskan sebagai ornamentasi di antaranya seperti urutan akord yang mencolok, tema melodi, harmoni, motif berirama, istirahat, catatan biru, catatan kotor merupakan fakta sebagai efek individu yang digunakan untuk memperkenalkan sesuatu khas yang berbeda dalam menampilkan bakat atau keahlian. Hal ini dikarenakan ornamentasi menempati posisi musik strategis sehingga mudah dihadirkan namun dianggap sebagai hiasan karena tidak dimediasi oleh semua secara keseluruhan.

Dari transkripsi notasi lagu yang dibawakan (E.L) pada acara Haul Gusdur di Magelang dapat diketahui bahwa unsur musikal didalamnya merupakan cengkok yang diolah sedemikian rupa dengan gaya yang lebih ngepop membuatnya semakin menarik dan berbeda. Misalnya cengkok dari wilayah pesisir timur yaitu daerah Banyuwangi yang dibawakan (EL).

Jangkauan nada yang dominan tinggi kemudian ada pengulangan cengkok berkalikali namun memiliki ketebalan suara yang berbeda. Jika dilihat alur nadanya kadangkadang meruncing, patah-patah, bergelombang teratur dengan perubahan pada ketebalan vokal yang berangsur semakin tipis. Selain itu penekanan suara ala jazz disajikan saat cengkok ini dimunculkan sebagai interpretasikan seorang sindhen lintas genre. Perlu diingat kembali bahwa kemampuan memberikan aksen, penekanan intonasi dari (E.L) tersebut diperoleh dari kumpulan sari pengalaman pribadinya yang bersinggungan langsung dengan beberapa lagu-lagu etnis yang digelutinya. Nyanyian itu akan memiliki perbedaan rasa jika yang menyanyikan memiliki latar belakang musik yang berbeda.

Berikut merupakan contoh lagu yang pernah dibawakan (EL). Penulis mengambil sampel lagu ini karena terdapat beberapa cengkok yang muncul dalam lagu tersebut.

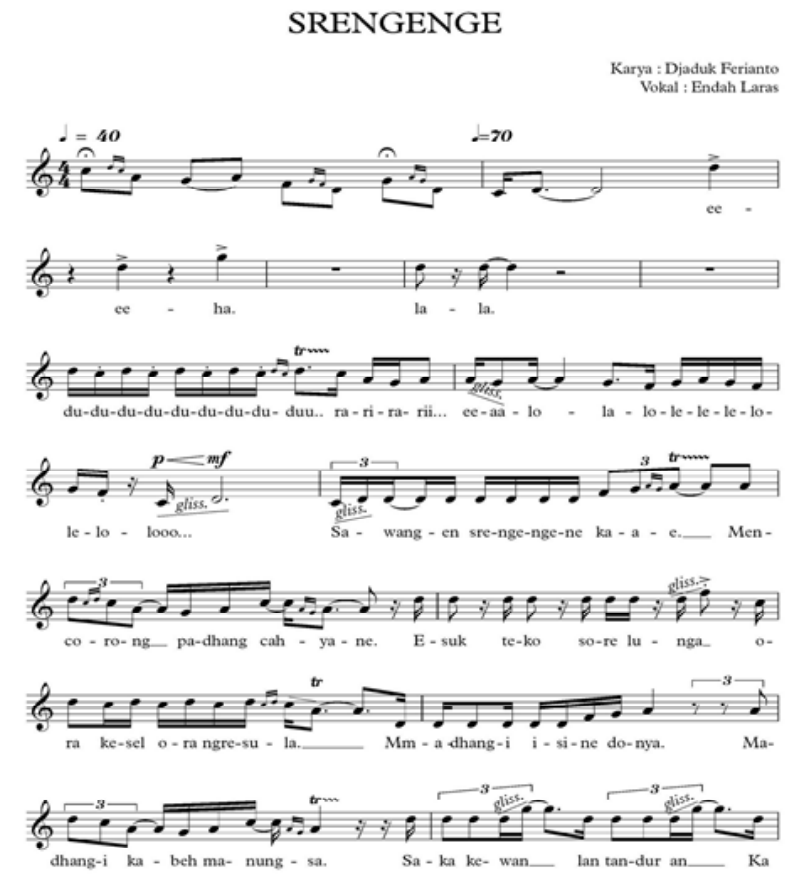

Gambar 6: notasi lagu dengan beberapa cengkok yang muncul dibawakan (EL)

Keterangan simbol:

gltss.: glissendo $=$ dalam sindhen disebut dengan $l u k$

$:$ mordent $=$ dalam sindhen disebut dengan $l u k$

$\geq$ : tekanan aksen

trm $:$ trill $=$ vibrasi $=$ gregel

Berdasarkan konsep Witkin dapat ditarik bahwa ornamentasi musik tersebut berlaku juga untuk vokal meski tidak tercantum secara khusus di konsepnya. Beberapa detile tersebut yang dtuliskan kemudian diterapkan pada vokal hasilnya hampir sama. Ornamentasi pada vokal sama dengan improvisasi biasanya bersifat spontan, namun direncanakan pun bisa tujuannya supaya lagu yang dibawakan tidak monoton, memperkaya nuansa, mempunyai ciri khas dan memiliki perbedaan dengan penyanyi lainnya. 
Kembali lagi bahwa improvisasi atau ornamentasi ini hanya bersifat hiasan karena yang utama adalah tema lagu atau melodi utama. Improvisasi ini akan menjadi sangat indah, bagus dengan catatan bahwa penyanyi mempunyai kepekaan telinga dan paham akan harmoni. Apabila tidak memiliki keduanya maka bisa dibilang ngawur atau sembarangan hasilnya fals, tidak sesuai tempatnya.

(Srinati, 2007:80) mengatakan bahwa musik merupakan sebuah artefak tekstual yang tidak dapat direproduksi dalam jumlah besar melalui teknik perakitan sehingga hasilnya adalah sebuah lagu khas atau unik oleh sekelompok penyanyi, musisi, aranger dan sebagainya. Musik pop sebagai hasil industri budaya yang didominasi oleh standarisasi (semakin banyak kemiripan) dan individualisasi semu _ perbedaan yang sifatnya kebetulan (Srinati, 2007:70-76). Dalam hal ini semakin banyak lagu-lagu yang distandarkan semakin banyak juga telinga yang diindividualisasikan. Standarisasi mengacu pada kemiripan musik pada bagian, bentuk maupun akornya, sedangkan individualisasi semu menyamarkan dengan menjadikan musik semakin bervariasi dan berlainan satu sama lain.

Untuk lagu pop yang sering dibawakan para sindhen lintas genre ini terutama lagulagu yang familiar di telinga para pecinta musik pasti tidak begitu menarik perhtian ketika sajiannya sama persis dengan pelantun sebelumnya atau bahkan memiliki kualitas dibawahnya. Namun pada kenyataannya berbanding terbalik bagi sindhen lintas genre. mereka melakukan dengan lebih baik sehingga saat mereka akan pentas selalu dinantikan para audien.

Cara mereka menarik perhatian para audien adalah dengan memberikan hiasan berbagai cengkok sehingga memberikan variasi kebaruan lagu tersebut. Lagu -lagu yang dibawakan serasa lebih hidup, dampaknya tidak sedikit lagu-lagu yang menjadi ciri khas dari para sindhen lintas genre. Selain itu masih ada modal lain yang bisa menunjukkan khasnya seseorang yaitu materi suara (pemberian sang pencipta) dan ciri khas style vokal (diperoleh dengan kebiasaan).

Dari kedua konsep tersebut diperoleh pemahaman bahwa musik sebagai barang yang tidak bisa diproduksi secara massal karena memiliki rasa individualitas yang berbeda-beda. Meskipun materi lagu yang dibawakan sama namun beda penyanyi beda pula hasilnya. Contoh perbedaan tersebut terlekat pada bagian cengkok atau ornamentasi. Meskipun hanya sebatas hiasan seperti yang dikatakan Witkin namun mampu menjadi daya tarik tersendiri bagi pendengarnya. Keberagaman tersebut semakin menambah banyak warna musik yang ada.

\section{Perubahan Status Sosial Pada Sindhen}

Adorno mengatakan bahwa ada perbedaan musik berdasarkan strata sosial. Musik klasik identik dengan masyarakat kelas atas sedangkan musik pop untuk kelas menengah dan bawah. Golongan musik klasik diperuntukkan bagi mereka yang pekerjaan atau kedudukan sosialnya memiliki waktu senggang dan tidak perlu melepaskan kejenuhannya. Sedangkan dalam musik pop diperuntukkan bagi yang mendapatkan kelakuan "kerja yang dimekanisasi" dan berkarakter berulang-ulang, standarisasi dan membosankan sehingga musik ini bisa didengarkan sambil lalu (ciri masyarakat kapitalis) karena tidak banyak menuntut atau kesulitan.

Masyarakat pada umumnya, menyebutkan sindhen bagian dari ansambel karawitan, diidentikkan dengan strata sosial musik klasik untuk kelas atas. Pernyataan tersebut muncul karena gamelan dianggap oleh masyarakat sebagai salah satu legitimasi adanya kebudayaan kerajaan, termasuk sindhen didalamnya. Masyarakat Jawa sendiri memandang bahwa predikat sindhen yang disandang seseorang adalah nama penghargaan tinggi lengkap dengan ilmu, kepribadian dan tahu akan akar tradisinya. Sehingga masyarakat karawitan mempunyai tolok ukur tersendiri akan penilaian tentang 
sindhen. Tidak serta merta orang yang bisa menyanyikan sedikit lenggak lengok bisa dikatakan sebagai sindhen.

Namun bagi sebagian masyarakat, citra sindhen terutama diluar tembok kraton sering dianggap sebagai hiburan kaum tua, bahkan sering kali dipandang sebelah mata bahwa sindhen merupakan sosok wanita penghibur dengan tradisi menari dan menyanyi. Hiburan wanita sangatlah erat dengan gagasan kebebasan seksual perempuan dan prostitusi dengan penyebutan kata "taledhek".

Adanya dikotomi mengenai status sosial di masyarakat Indonesia ini (Srinati, 2007:7076) menjelaskan bahwa musik pop dianggap sebagai perekat sosial karena kenikmatan dan katarsismenya berusaha mengkonstruk sebuah masyarakat yang individunya bisa bebas, bahagia dan terpenuhi. Dengan adanya peluang akan animo kesenian di masyarakat, kesempatan ini disambut baik oleh para sindhen lintas genre. Dengan terjun ke wilayah pop maka sindhen berusaha meleburkan diri dengan mengesampingkan kelas masyarakat yang memberikan jarak antara masyarakat kelas atas ataupun masyarakat kelas bawah.

Hadirnya sindhen lintas genre di hadapan publik dengan tampilan yang berbeda (sindhen dengan tampilan pop) membuat masyarakat menjadi lebih tertarik untuk mengikutinya. Dari kaum muda maupun tua, dari masyarakat desa sampai masyarakat kota, dari domestik maupun manca negara sangat antusias dengan kehadiran sindhen tersebut. Selain disebabkan style sindhennya juga karena sajian musiknya. Istilah "Sindhen" yang digunakkan sebagai salah satu label industri merupakan salah satu cara untuk mengangkat kembali sindhen di hati masyarakat.

Selain itu bagi seorang sindhen momentum ini digunakan sebagai jalan keluar atas "kejenuhan" dari tekanan "budaya adiluhung" yang tidak memberikan kontribusi pada kepentingan eksistensi pelaku seni. Dengan mencari celah yang memungkinkan, para sindhen mencari terobosan baru dengan menambahkan sedikit keberanian untuk melangkah ke ranah lain dengan berpijak dari akar tradisinya.
Tuntutan masyarakat yang selalu menginginkan perubahan pada karya seni khususnya musik memaksa para sindhen untuk bersikap kreatif mendapatkan tempat di masyarakat secara luas. Hasilnya adalah cengkok yang dilantunkan oleh sindhen lintas genre mempunyai keunikan tersendiri. Cengkok sindhen lintas genre tersebut hadir pada nyanyiannya bukan semata-mata ngawur. Perlu ditarik kembali latarbelakang dari sindhen tersebut sehingga mampu menyajikan lagu-lagu yang kaya akan cengkok.

Hal ini tampak berbeda pada sebagian sindhen yang tidak bisa bernyanyi. Faktanya, mereka kesulitan untuk melepas cengkok sindhen murninya saat melantunkan lagu pop. Penyebabnya ada pada diri masing-masing sindhen yang menempatkan dirinya berada pada ranah kelas atas " Adiluhung". Sehingga beban beban etnosentris dalam dirinya menutupi kemauan dan kemampuan dirinya di lain sisi. Meskipun metode dan cara belajar yang digunakan hampir sama.

Melihat keadaan tersebut istilah sindhen yang digunakan dalam industri hiburan mengalami perubahan. Karena orientasi pelaku seni menggunakan seninya tidak lagi sebagai pengalaman estetis namun lebih kepada barang dagangan yang bergantung pada tuntutan pasar. Sehingga sifat misterius dari sindhen semakin pudar ketika label sindhen dihargai dengan uang. Hal tersebut memberikan dampak pada perubahan pemaknaan profesi sindhen sendiri. Oleh karena itu masyarakat secara luas menyebutkan sindhen lintas genre sebagai label dari industri karena mereka berada pada posisi masyarakat Indonesia yang terdiri lebih dari satu etnis.

Dibalik itu semua Benjamin melihat dampak positif dari produksi massal tersebut. Selain lebih terbuka untuk dinikmati, diapresiasi, seni juga bisa diresepsi tanpa melihat perbedaan kelas masyarakat yang selama ini membatasi dan membuat dikotomi antara kelas bawah dan kelas atas (Benjamin 1968).

Dari konsep diatas dapat dipahami bahwa munculnya sindhen lintas genre 
menjadi sebuah fenomena yang mampu menjembatani dikotomi kelas masyarakat. Pasalnya mereka mempunyai cara mempersatukan masyarakat dengan karya sindhennya sehingga menyamarkan dikotomi tersebut. Dengan beragam cengkoknya yang membuat masyarakat kembali menengok pada profesi sindhen. Image sindhen sebagai salah satu legitimasi ke adiluhungan sebuah kebudayaan di Jawa menjadi memasyarakat ketika muncul dengan tampilan pop di televisi. Sehingga sindhen lintas genre mempunyai peran yang besar dalam mempersatukan kelas masyarakat Indonesia.

\section{Sindhen Lintas Genre dan Industri Hiburan}

Sindhen tidak bisa lepas dari tantangan dalam dunia hiburan. Baik dan tidaknya bergantung pada animo masyarakat. Saat ini sindhen berada di posisi beruntung berkat bantuan media elektronik yang secara cepat memasarkannya. Promosi ini berhasil dengan baik sehingga sindhen lintas genre ini memiliki tempat tersendiri di masyarakat. Munculnya sindhen lintas genre ini dianggap masyarakat sebagai hal baru karena sindhen sebelumnya tidak banyak bahkan mungkin belum ada yang melakukannya. Oleh sebab itu semakin banyak kesempatan untuk pentas semakin banyak juga peluang finansial yang diperolehnya.

Dibalik itu semua sindhen lintas genre tidak akan muncul apabila keadaan sindhen itu sendiri kurang mendapatkan dukungan dari lingkungan, memiliki pengalaman dan mempunyai cara belajar yang efisien. Dengan masuknya ke ranah industri sindhen dituntut untuk lebih kreatif dengan memiliki kemampuan dan ciri khas yang berbeda-beda sesuai kapasitasnya.

Ciri khas masing-masing sindhen ini terletak pada kemampuannya mengolah cengkok. Mereka sangat menyadari bahwa musik merupakan barang yang tidak bisa diproduksi secara massal karena memiliki rasa individualitas yang berbeda-beda. Oleh karena itu cengkok-cengkok yang dikemas (gaya pop) sedemikian rupa kemudian dibawakan dengan nuansa berbeda mampu menjadi daya tarik tersendiri. Dari ornamentasi/cengkok yang hanya dimaknai sebagai hiasan namun mampu membuat warna musik lebih kelihatan berbeda. Cengkok tersebut sebagai salah satu cara bagi diri mereka untuk tetap mempertahankan keeksisannya di dunia industri hiburan.

Dampak yang munculnya bahwa sindhen lintas genre dengan beragam cengkoknya menjadi sebuah jembatan dikotomi kelas masyarakat. Cara yang menarik untuk mempersatukannya karena berkat cengkoknya semua masyarakat dari Sabang sampai Merauke mampu mengenal sindhen secara cepat tanpa ada ketakutan kelas sosial. Keberadaan sindhen ini menjadi lebih dekat dengan masyarakat meski ada pergeseran makna sindhen yang digunakan sebagai label industri dan makna sindhen yang ada di masyarakat Jawa sendiri. Sisi positifnya bahwa sindhen kembali dikenal masyarakat secara luas berkat ketrampilan yang dimiliki dan didukung oleh media.

\section{Kesimpulan}

Faktor yang membuat seorang sindhen masuk ke ranah populer adalah faktor eksistensi. Mempunyai jadwal pentas padat, wilayah pentas yang luas, merambah ke berbagai genre musik dengan kemampuan cengkoknya sehingga mencakup lebih banyak kalangan, maka akan berdampak pada peningkatan aspek ekonomi.Upaya yang dilakukan para sindhen lintas genre adalah dengan belajar mendengarkan berbagai cengkok-cengkok dan karakter lagu dari berbagai macam genre. Selanjutnya melatih cengkok-cengkok tersebut terus menerus hingga para sindhen lintas genre mendapatkan rasa/ruh dari lagu tersebut.Sebagian sindhen yang tidak bisa bernyanyi karena memiliki beban kultural. Menyandang predikat sindhen (adiluhung) memberikan pandangan bahwa sisi selain sindhen dianggap sebagai kelas rendah sehingga secara tidak sadar mempengaruhi tekhnik bernyanyinya, oleh karena itu ketika bernyanyi genre lagu (selain sindhen) rasa/ ruh (cengkok sindhennya) tidak bisa lepas. 


\section{Kepustakaan}

Budiarti, M. (Desember 2013),"konsep kepesindenan dan Elemen-Elemen Dasarnya" dalam Harmonia, Volume 13 , no 2

Budiarto, C.Teguh . 2001. Musik Modern dan Ideologi Pasar. Yogyakarta: Tarawang Press

Caturwati. 2005. Sinden-penari diatas dan diluar panggung : kehidupan sosial budaya para sindhen-penari kliningan jaipongan di wilayah subang jabar, Yogyakarta, UGM

Djohan. 2003. Psikologi Musik. Yogyakarta: Buku baik

Hargreaves, David. J. Dan Adrian C. North (Terj.)1997. The Social of psychology of Music. Oxford : University press

Jazuli, M. 2009. Popularitas Sinden. Harmonia : Jurnal Pengetahuan dan Pemikiran Seni. Vol. 9 No. 2 Hal. 85-94

Luq. (25 September 2004), “Sinden Ditinggalkan karena Penghasilan Minim * Dikbud", Kompas.

MM/ DTH/ TOP/ BRE. (8 Maret 1999), “ Sinden: Berlalunya Mitos Lama..", Kompas.

Poerwadarminta,W.J.S. 1939. Baoesastra Djawa. Batavia: J.B Wolters Uitgrevers Maatschappij N.V. Groningen

Sartono,frans; Suwarna, Budi. (21 Maret 2010), "Balada Pesinden "Mbalelo" ", Kompas.
Sartono, Frans . ( 11 November 2007), “Musik: Peni: Sinden di Tengah Jazz", Kompas.

Soeroso. 1999. Kamus Istilah Karawitan Jawa. Yogyakarta

Srinati, Dominic (terj). 2007. Popular Culture pengantar menuju teori Budaya Populer. Yogyakarta: Jejak

TOP/ASA/BRE. (16 November 1996), "Menziarahi Dunia Sinden", Kompas.

Zoetmulder P.J, 2011. Kamus Jawa KunaIndonesia. Jakarta: PT. Gramedia Pustaka Utama

\section{Webtografi}

Candrarini, Peni, "Kekuatan sindhen kontemporer" kompas.com

Purnomo Sapto (19 Mei 2014) "Soimah siap rilis album dangdut" Liputan 6.com

Respati Sruti (3 Maret 2013)"Sruti Respati dan musim sinden naik daun " BBC Indonesia

Soimah (15 oktober 2015) “ Soimah berani tampil beda" bintang.com

http://www.krjogja.com/web/news/read/ 277669/inilah_sinden_manca_ negara

http://www.suaramerdeka.com/harian/ 0307/04/slo8.htm

http://www.antarajatim.com/lihat/berita/ 112926/endah-laras-pentas-musiktradisional-ke-jepang 